\title{
Observation - A Part of Kindergarten Teachers' Professional Skill Set
}

\author{
Johanna Birkeland \\ Western Norway University of Applied Sciences, Bergen, Norway
}

Copyright $\mathrm{C} 2019$ by authors, all rights reserved. Authors agree that this article remains permanently open access under the terms of the Creative Commons Attribution License 4.0 International License

\begin{abstract}
Knowledge and skills in observation form part of the qualifications a kindergarten teacher needs to become a professional. In this article, I will focus on the theme of observation in kindergarten teacher education (KTE) in Norway. One of the largest educational institutions in the country is used as reference for this study. By means of document analysis, the intended learning outcomes in observation are studied at a societal and institutional level. The purpose of the study is to gain insight into the rationale for observation in the educational context, to identify which observational methods are emphasized, and what students should focus on in their observation work. The results reveal that the intended learning outcomes in observation vary depending on the disciplinary profiles the students have chosen. The study also reveals shortcomings between the societal and institutional levels, as well as a need for discussion and clarification of key observation methods in a profession-oriented education, in line with recent perspectives on children, where children are seen as participants. The results might raise questions about the organization of KTE and whether the theme of observation is research-based and profession-oriented.
\end{abstract}

Keywords EEC-teacher Education, Kindergarten Teacher, Learning Outcomes, Observation, Professional Knowledge, Profession-oriented

\section{Introduction}

In 2012, a new curriculum for the Norwegian Kindergarten Teacher Education (KTE) ${ }^{1}$ was introduced. The radical shifts brought by the reform included the

1 The KTE curriculum, approved in 2012 and introduced in 2013, includes the National KTE Regulations, Regulatory KTE Annotations, as well as National KTE Guidelines.

https://www.regjeringen.no/no/dokumenter/nasjonal-forskrift-om-ramme plan-for-barn/id684087/ previous academic disciplines being amalgamated into six interdisciplinary areas of expertise, into which practice is integrated [1]. Academically strong, research-based, profession-oriented and functional organization suited to the objectives of the education programmes are overarching goals [2:7]. KTE is run according to defined learning outcomes, which describe the learning the education is intended to provide, and which the students can be tested on [1]. One of the objectives is for "the student to have knowledge of observation and pedagogical documentation as a prerequisite for the didactic alignment to children's playing and learning processes, and to the play and learning environment in the kindergarten" [3:15]. This is one of the learning objectives that pertains to observation. Observation should thus constitute an element in teacher education so that future kindergarten teachers have such knowledge and skills for observation as part of their professional expertise.

Inspired by Haakstad [4], this study investigates the intended learning outcomes regarding observation at KTE. The background to this article is an analysis of documents [5] regarding national and local KTE protocols at one of Norway's largest educational institutions for kindergarten teacher education. The research question behind this article is: How are the descriptions of the learning outcomes regarding observation in the KTE curricular framework brought to bear in the kindergarten teacher education at Western Norway University of Applied Sciences - (HVL)?

\subsection{Learning Outcomes - as Intended Knowledge and Skills}

White Paper no. 16 (2016-2017) The Culture for Quality in Education points out that good education/training must provide clear learning outcome descriptions that permit educators, students and society at large to know what actual skill set students possess upon graduation [6].

A common definition of a learning outcome is Otter's (1992) definition: "What a learner knows or can do as a result of a learning process" [4:72]. This is a simple and comprehensive definition, but it is not exhaustive. 
Learning outcomes include what the student is left with, intended or otherwise. Haakstad[4] points out that a distinction must be made between intended learning outcomes taken as learning goals and learning outcomes in the sense of learning results. The focus for the study is the intended learning outcome in observation, as is presented in the national provisions for KTE and in the course descriptions, work requirements and syllabus at HVL.

In the notes on the Regulatory KTE Annotations [1], it is pointed out that the learning outcomes for students are formulated according to the National Higher Education Qualification Framework (2009). The expected learning outcomes are described here in the categories of Knowledge, Skills and General Competence:

Knowledge: Factual knowledge, conceptual knowledge, procedural knowledge, metacognitive knowledge.

Skill: Ability to use acquired knowledge and/or executive or creative abilities.

Competence: General skills acquired/mastered through professional studies, and which may have transfer value in future professional application.

In my analysis and presentation, skills and general skills are merged into one category: skills. Two categories result

1) Knowledge of observation

2) Observation skills

\subsection{Theoretical Framework of the Study}

Inspired by Hedegaard [7], I will use a holistic, culture-historical approach and analysis that integrates three levels: Society, Institutions and the Individual.

The community level provides guidance for institutional practice. "It reflects historically evolved traditions in a society that are formalized into laws and regulations as conditions for the existence of an institution" [7:129]. Relevant to this study, this section incorporates national governance documents for education; Regulations regarding the framework plan for KTE [8] and the National KTE Guidelines [3].

The institutional level "reflects informal conventional traditions and demands taking form as practices i.e. in school and kindergarten" [7:130], "organized within a society that have their own procedures/rules and traditions" [9:153). For students studying to be kindergarten teachers, the institutional level means learning about observation in two "activity settings" [7:131]; at college and during their internship in the kindergarten. This is also how kindergarten institutional practice influences and creates conditions for student learning about observation. In this study, the focus is limited to the college institution. The individual institution's practices and values, embodied in the course descriptions for teaching and practice, as well as reading lists and compulsory work involving observation in the field, are institutional requirements for student learning about observation in the 3-year kindergarten teacher training.

The individual level is defined as "a specific plane that reflects the shared activity settings of persons in a specific institution" [7:130]. Learning about observation involves teachers, practice teachers and students. The teacher educator has their aims (developed in line with the legislation, expert knowledge and experience) and activities (teaching, practice visits, guidance, cooperation) that in turn are about influencing/shaping/participating in different 'activity settings' (Campus Teaching/ Practice), so that students develop knowledge and skills in observation. In this way, the trainer educator's activity and motives also set the stage for the students' learning about observation.

In this article, the focus is narrowed down to the community and institution level, which involves analysing documents that determine how students learn about observation in KTE.

\subsection{Previous Research Relevant to the Study}

In a Swedish review of the data [10] on assessment (bedömning) and documentation work in the preschool and early school years, it appears that observation is included in the documentation and assessment work, where observation and other documentation form the basis for the assessment. It also appears that observation, documentation and assessment work is based in great measure on a developmental psychology approach to children. Several scholars have problematized the fact that the setting and organization themselves are not focused on in observation and documentation work [11-15].

Internationally, developmental psychology has dominated [16], with its focus on the observation of the individual child in accordance with normal development. In keeping with recent views on children and children's development, where children are seen as participants $[9,13,17]$ and the importance of the context for learning, the development and the understanding of children is central, a shift towards group observations and a sociocultural anchoring of observation work has occurred [16]. Elfström [12] points in her thesis to the emergence of developmental psychology in the 1930s, and how it laid the foundation for a tradition of observation of individual children for the purposes of classifying the child's development in relation to predetermined categories borrowed from Developmental Psychology. Birkeland \& Ødegaard's [18] study among 180 kindergarten teachers shows that the observations made in Norwegian kindergartens today are still anchored in a developmental psychology paradigm, even as interaction is given as the primary focus of the observations being made. Their study indicates that the contribution of the adult in the interaction with children seems to be a blind spot. This is in line with the findings of Kallestad and Ødegaard's [19] study, in which kindergarten teachers from 30 kindergartens observed activities and how these proceeded in the kindergarten. In this study, it is apparent that kindergarten teachers did not note down what they themselves did in the participant observations. Thoresen [20] also points out that 
greater attention has to be paid to the adult, out of an ethical concern, considering the asymmetry between adults and children. In particular, Thoresen points to the need for an emphasis on ethics; of ethical reflection in kindergarten teacher training.

Bjerkestrand et al. [21] show that most educational institutions in Norway use the methodological book Observation and interview in the kindergarten. Here, observation is defined as a threefold process: 1 . The actual observation (use of the senses), 2. Description of the observation (the record) and 3. Interpretation of the observation. "With the help of the senses, we record what is happening around us; we note down what we observe and interpret it afterward" [22:40]. Perception is the foundation of observation. Both perception and the taking of notes are undertaken at the individual level. The record acquires meaning, as the basis for individual and collective reflection and validation of one's own interpretations in contrast to others'.

Kindergarten teacher education should be profession oriented and defined as an education that is relevant to the profession students are to be trained for [23:24]. In Norwegian kindergartens, observation is emphasized as the basis for assessing the health, wellbeing, experience, development and learning of a single child. Planning, assessment and documentation are considered in this context. Assessment is seen as a process, in which educational work is described, analysed and interpreted. The purpose of assessment work is to ensure that all children are provided for in accordance with the Kindergarten Act and the current framework. Documentation of the work of the personnel highlights how they work towards meeting the requirements. The significance of collective reflection is emphasized, so that staff can learn from their own practice and develop the kindergarten as an educational instance [24].

\section{Materials and Methods}

To answer the question: How are the descriptions of the learning outcomes regarding observation in the KTE curricular framework brought to bear in the kindergarten teacher education at HVL? Document analysis has been chosen as the methodical approach. Bowen [5:27] defines document analysis as "A systematic procedure for reviewing or evaluating documents. Like other analytical methods in qualitative research, document analysis requires that data be examined and interpreted in order to elicit meaning, gain understanding, and develop empirical knowledge". The intention has not been to evaluate the selected documents, but to carry out a review in order to reveal and understand how observation manifests at the societal and institutional level, as well as how and whether the level of community ordinances is realized at the institutional level in HVL's course syllabuses and compulsory work requirements for the students. The documents incorporated into the study are:

- Regulations on the Framework Plan for KTE [8]

- Notes on the Regulation Guidelines for KTE [1]

- National Guidelines for KTE [3]

- Course syllabuses for KTE at selected colleges

- Compulsory work requirements for the training of the 3-year KTE at selected colleges.

I started by reading through the material to get an overview. I then extracted all the text that dealt with observation. My background as a teacher of pedagogical theory, with expert knowledge of observation, whilst leaning on previous research, was here instrumental in what was "identified as pertinent information" [5:32]. Moreover, I went through all the work requirements in the training curriculum, and took out those that dealt with observation, which was limited to practice tasks. I then used the "Predefined Codes" [5] based on the National Qualification Framework that were merged into two categories: Knowledge and Skills, as previously described. Finally, the results of the document analysis at the two levels; the community and institution levels [7]; were synthesized for the purposes of comparison. In addition, the syllabus was reviewed to identify its provisions for observation.

The choice of method and procedure was appropriate for building an image of the intended learning outcomes regarding observation in KTE. However, the study is limited to a sole institution. Each educational institution that offers kindergarten education in Norway must base their course syllabuses on the national guidelines when drawing them up. A study carried out at other institutions might produce different results. Here I see the need for a further study; one which incorporates several educational institutions, in order to validate and broaden the findings of this study. The individual level is not clarified and must also be addressed.

\section{Result}

\subsection{Observation - as Knowledge and Skills at the Societal Level}

The result of the document analysis at the societal level [7] is given in Table 1, pertaining to the six areas of expertise in education, as well as practice and work on the Bachelor dissertation that the students undertake to write in the latter part of their education. The areas of expertise are:

BULL: Children's Development, Play and Learning

STM: Language, Texts and Mathematics

NHB: Nature, Health and Movement

KKK: Art, Culture and Creativity

SRLE: Society, Religion, Spirituality and Ethics

LSU: Leadership, Cooperation and Development work.

The table lists the requirements for knowledge and skills that are relevant to observation. 
Table 1. Learning Outcome Description of Knowledge and Skills Pertaining to Observation at the Societal Level*

\begin{tabular}{|c|c|c|}
\hline $\begin{array}{l}\text { Knowledge } \\
\text { area: }\end{array}$ & Knowledge & Skills \\
\hline BULL & $\begin{array}{l}\text { The student shall have knowledge of observation and pedagogical } \\
\text { documentation as a prerequisite for the didactic provision for children's } \\
\text { play and learning processes and for the play and learning environment in } \\
\text { the kindergarten. }\end{array}$ & \\
\hline STM & & $\begin{array}{l}\text { Can observe, facilitate, chart and track } \\
\text { children's development in language and } \\
\text { mathematics. }\end{array}$ \\
\hline NHB & & $\begin{array}{l}\text { An important part of professional expertise is } \\
\text { to be able to observe, analyse and understand } \\
\text { the development of children. }\end{array}$ \\
\hline KKK & & $\begin{array}{l}\text { Can plan, execute, document and evaluate } \\
\text { artistic and creative educational processes } \\
\text { with/for children. }\end{array}$ \\
\hline SRLE & - & - \\
\hline LSU & $\begin{array}{l}\text { Has knowledge of relevant research, methodologies and tools as a basis } \\
\text { for management and development work. }\end{array}$ & $\begin{array}{l}\text { Can plan, justify, execute, document and } \\
\text { assess educational work. } \\
\text { Can adopt suitable methods and tools in work } \\
\text { with developmental and learning processes. } \\
\text { Can reflect on their own and the } \\
\text { kindergarten's practice. }\end{array}$ \\
\hline $\begin{array}{l}\text { Practical } \\
\text { training }\end{array}$ & & $\begin{array}{l}\text { The student shall have the opportunity to be } \\
\text { both participator, experimenter and observer } \\
\text { in educational activities in the kindergarten. }\end{array}$ \\
\hline $\begin{array}{l}\text { Bachelor } \\
\text { dissertation: }\end{array}$ & $\begin{array}{l}\text { In connection with the Bachelor's dissertation, the institutions will } \\
\text { provide students with an introduction to the theoretical perspective of } \\
\text { science and relevant methods/work practices within research and } \\
\text { development work. }\end{array}$ & \\
\hline
\end{tabular}

* Regulations on the Framework Plan for KTE, Notes on Regulations regarding KTE Framework Plan, National KTE Guidelines

We see that knowledge and skills in observation are associated with didactic work, children's play and learning processes, the play and learning environment; with children's versatile development, as well as with assessment, reflection and the development of educational practices. Lessons in epistemology and relevant methods should be included in the education. The intended learning outcomes [4] incorporate both knowledge and skills in observation; observation is impacted by all areas of knowledge, with the exception of SRLE (society, religion, spirituality and ethics). In the knowledge field of STM (language, text and mathematics), mapping ability also appears as part of the intended learning outcomes. The student should be able to both observe and chart progress. Observation should also be included in the internship.

\subsection{Observation - by Way of Knowledge and Skills at the Institutional Level}

Table 2 shows how knowledge and skills in observation feature in the course syllabuses delimited to all subjects, which feature in the curriculum for all students. The corresponding compulsory work requirements (practice tasks) are included to give an idea of each area of knowledge into which practice is integrated. In addition, the subject plan applies to practice in the 1st, 2nd and 3rd years of study inclusively, as is also the case for all the students being educated at HVL. Moreover, in the course of their training, the students immerse themselves in one of the following areas of knowledge: BULL, STM, NHB or KKK, depending on the profile they have chosen.

We see that at the institutional level [7], observation is associated with the observation of children, children's groups, the learning environment/management, as well as for working with change and development processes. Play, language, motor skills and mathematics development should be observed. Students should have a good grasp of key observation methods, and they should have the skills to use the methodology in line with the three-step observation process [22], which implies reflection and the submission of a written memorandum. The methods implemented are participatory observation, ongoing protocols, stories from practice, and sound recordings. Stories from practice take precedence in terms of their scope. Epistemology and ethics are implicated.

In NHB (Nature, Health and Movement) observation is "an important part of the professional expertise" at the societal level (table 1), but is not incorporated at the institutional level in the NHB field of knowledge. In one knowledge area, KKK1, children's involvement and their role as participants $[8,12]$ is made explicit. Here "children's voices" and "children's interest" are implicated in the documentation, reflection and didactic work. 
Table 2. Learning outcome Description of Knowledge and Skills Pertaining to Observation at the Institutional Level; All Students.

\begin{tabular}{|c|c|c|c|}
\hline $\begin{array}{l}\text { Subject } \\
\text { plan } \\
2015 / 2016 \text { : }\end{array}$ & Knowledge & Skills & Compulsory coursework requirements \\
\hline BULL1 & $\begin{array}{l}\text { Knowledge of key } \\
\text { observation methods }\end{array}$ & $\begin{array}{l}\text { Use different methods to observe children, } \\
\text { children's groups and learning } \\
\text { environments, as well as produce written } \\
\text { observations }\end{array}$ & $\begin{array}{l}\text { 1) Observation of play by means of an ongoing } \\
\text { protocol, participatory observation and stories } \\
\text { from practice } \\
\text { 2) Observation of children's motor skills in } \\
\text { accordance with the ongoing protocol }\end{array}$ \\
\hline STM1 & & $\begin{array}{l}\text { Can observe and provide for the children's } \\
\text { language and maths development }\end{array}$ & $\begin{array}{l}\text { Writing at least } 3 \text { stories from practice that } \\
\text { reflect academic issues from STM. Plan thus and } \\
\text { conduct an activity/everyday conversation with } \\
\text { sound recordings }\end{array}$ \\
\hline NHB1 & - & - & - \\
\hline KKK1 & & $\begin{array}{l}\text { Can plan, execute, document and evaluate } \\
\text { art education processes }\end{array}$ & $\begin{array}{l}\text { Document and reflect on an unusual } \\
\text { kindergarten group assembly. Children's 'voices' } \\
\text { should be the weighted element in the work, in } \\
\text { order to build on children's interests }\end{array}$ \\
\hline LSU1 & & $\begin{array}{l}\text { Can make use of methods and tools related } \\
\text { to change and development processes }\end{array}$ & Conduct development work in kindergarten. \\
\hline $\mathrm{BACH}$ & $\begin{array}{l}\text { Can assess research } \\
\text { methods with relevance } \\
\text { to management studies. }\end{array}$ & $\begin{array}{l}\text { Can refer to epistemological and } \\
\text { methodological knowledge }\end{array}$ & \\
\hline PRAKSIS1 & & $\begin{array}{l}\text { Work in accordance with ethical } \\
\text { requirements and guidelines in the } \\
\text { observation of children and children's } \\
\text { groups and document observations in } \\
\text { writing. }\end{array}$ & $\begin{array}{l}\text { The student is advised to write stories from } \\
\text { practice every day }\end{array}$ \\
\hline PRAKSIS2 & & $\begin{array}{l}\text { Utilize pedagogical literature as a tool in } \\
\text { educational work }\end{array}$ & $\begin{array}{l}\text { The student is advised to write stories from } \\
\text { practice every day }\end{array}$ \\
\hline PRAKSIS3 & & $\begin{array}{l}\text { Apply different documentation as a tool in } \\
\text { changing the work focus }\end{array}$ & \\
\hline
\end{tabular}

Table 3 shows the result of document analysis of the course syllabuses in the knowledge areas students can immerse themselves in, which are found in the 4 fixed profiles students can choose from: Either BULL $2+3$., STM $2+3$, KKK 2 +3 or NHB $2+3$.

We see that, depending on the profile the students choose, the intended learning outcomes [4] for observation are very different. In the KKK profile (art, culture and creativity), ICT seems to be linked to observation work, because ICT is seen as a tool for documentation and reflection. In BULL (children, development, play and learning), we see that digital tools such as photography should be used in work requirements for practice. In BULL, students will also be able to use sociograms, something we do not find in the other profiles. BULL observations focus on the environment and on management. In STM (language, text and mathematics), students should use $\mathrm{MIO}^{2}$ and TRAS ${ }^{3}$. Observation work is linked with focus on the child, where children's language development and mathematical development are mapped. The students should be able to critically evaluate the use of mapping tools as a method in kindergarten, as well as consider the use of different methodologies in observation and documentation work. In NHB (nature, health and movement), students should have "knowledge of the meaning of systematic observation". In this area of expertise we find a practice task related to observation, but it is unclear whether and ultimately which observation methods are to be emphasized. 
Table 3. Learning Outcome Description as Per the Knowledge and Skill in Observation at the Institutional Level in the 4 Profiles

\begin{tabular}{|c|c|c|c|}
\hline Subject plan & Knowledge & Skills & Compulsory work requirements \\
\hline BULL2 & & $\begin{array}{l}\text { Use the knowledge of observation } \\
\text { as the basis for the planning, } \\
\text { implementation, assessment and } \\
\text { documentation of the running of the } \\
\text { kindergarten. }\end{array}$ & $\begin{array}{l}\text { At least } 3 \text { different observations of children's } \\
\text { friendship, through the use of sociograms and } \\
\text { participatory observation/ongoing } \\
\text { protocol/stories from practice. } \\
\text { Mapping the kindergarten's language } \\
\text { environment using observation methods. } \\
\text { Substantiate activities to be documented with } \\
\text { photos, audio recordings and written reports. }\end{array}$ \\
\hline BULL3 & & & $\begin{array}{l}\text { Take pictures and document the visual } \\
\text { culture of the kindergarten to analyse a } \\
\text { selected area and reflect on the space as the } \\
\text { third educational instance. }\end{array}$ \\
\hline STM2 & & $\begin{array}{l}\text { Can observe, facilitate, chart and } \\
\text { track children's development in } \\
\text { language and mathematics. } \\
\text { Can critically evaluate the use of } \\
\text { mapping tools as a method in } \\
\text { kindergarten, as well as consider the } \\
\text { use of different methods in } \\
\text { observation and documentation } \\
\text { work. }\end{array}$ & $\begin{array}{l}\text { Charting at least one child's mathematical } \\
\text { development through the use of MIO and } \\
\text { other observational methods. } \\
\text { Charting at least one child's language } \\
\text { development through the use of TRAS and } \\
\text { other observational methods. }\end{array}$ \\
\hline STM3 & & $\begin{array}{l}\text { Can assess methods from a } \\
\text { professional perspective. }\end{array}$ & \\
\hline KKK2 & $\begin{array}{l}\text { ICT (Information and } \\
\text { Communications Technology) } \\
\text { as a tool for documentation and } \\
\text { reflection. }\end{array}$ & $\begin{array}{l}\text { Can plan, execute, document, } \\
\text { evaluate and reflect on art education } \\
\text { processes. }\end{array}$ & $\begin{array}{l}\text { Lead a creative process. The "voice" of the } \\
\text { children should be a weighted element in this } \\
\text { work. The work is documented and actively } \\
\text { used as educational documentation. }\end{array}$ \\
\hline KKK3 & $\begin{array}{l}\text { ICT as a tool for } \\
\text { documentation, reflection and } \\
\text { as an independent tool for } \\
\text { aesthetic expression. }\end{array}$ & $\begin{array}{l}\text { Can initiate, lead, document, and } \\
\text { quality-secure kindergarten work in } \\
\text { alignment with the range of } \\
\text { expertise? } \\
\text { Can use educational documentation } \\
\text { as a tool for reflection. }\end{array}$ & \\
\hline NHB2 & $\begin{array}{l}\text { Knowledge of the significance } \\
\text { of systematic observation, } \\
\text { classification and } \\
\text { experimentation in the } \\
\text { exploration of nature. Have } \\
\text { knowledge of various } \\
\text { assessment forms and } \\
\text { educational documentation. }\end{array}$ & $\begin{array}{l}\text { Can plan, lead and evaluate } \\
\text { educational work with children. }\end{array}$ & $\begin{array}{l}\text { Registration using the inventory of what } \\
\text { is available of organic artefacts and } \\
\text { objects from nature in the kindergarten. } \\
\text { Observing how organic artefacts and } \\
\text { objects of natural origin are used. }\end{array}$ \\
\hline NHB3 & - & - & - \\
\hline
\end{tabular}

\subsection{Curriculum}

Review of the syllabus shows that literature with relevance for observation inherent in the individual subjects (for all students) deals with understanding children as part of a context, the observer role, educational documentation and methods: logbook, rating scales, time sampling, ongoing protocols, participatory observation, as well as stories from practice with anchoring in Louise Birkeland's [25] stories from practice concept ${ }^{4}$.The general reference work on observation, Løkken \& Søbstad [22], is limited to two chapters which are included in the individual subjects of all students. Students in the BULL profile

4 Birkeland's (1998) conceptualization of stories from practice, provides a space to use for observation, a basis for collective reflection for the evaluation of practice.
(Child Development, Play and Learning) are introduced to the rest of the book in their 2nd and 3rd subjects. Here we find, among other things, video observation in Chapter 4 of the book. This is not part of the syllabus in the other profiles. In the KKK (Art, Culture and Creativity) and NHB (Nature, Health and Movement) profiles, only Chapters 6 and 7 are referenced further on in the study, as there we find experiment, tests, sociometry and collections of children's productions. The STM (Language, Text and Mathematics) profile makes no further use of this book. Conversely, mapping is a topic in STM2. Here we find MIO and TRAS, which are not found in the other profiles.

There is considerable variation in what there is in the syllabus for students in relation to observation, depending on the profile they have chosen. The intended learning outcome [4] in observation, through reading literature, is not the same for all students who undertake to study at this 
institution. The different educational profiles give varying access to knowledge of observation through the selected reading for the profiles. Video observation is reserved for the BULL students. Sociometry is reserved for students who have chosen BULL, KKK or NHB; but as shown in Table 3, only BULL requires the use of the sociogram in practice. Mapping and tools such as MIO and TRAS are reserved for those students who have chosen the STM profile on their path to becoming a kindergarten teacher.

\subsection{Differences in Community and Institution Level Emphasis on Observation}

The study shows that knowledge and/or skills in observation will, according to the national KTE guidelines, be part of 5 of the 6 knowledge areas in the programme. This is reflected in HVL's course descriptions, but is realized somewhat differently than the guidance given in the national education framework.

BULL: At the societal level, observation is associated with didactic work, learning processes and the learning environment in the field of BULL (Child Development, Play and Learning). At the institutional level in BULL, observation is to the greatest extent associated with observation of children. At the deeper levels of BULL, for those students who choose it, the focus of observation efforts is more consistent with the national guidelines for this area of knowledge.

STM: At the societal level, observation and mapping are associated with children's language and mathematics development, and this is reflected at the institution level. Those who choose immersion in STM (Language, Text and Mathematics) become familiar with the monitoring tools MIO and TRAS, but the learning outcome, that is to say the intended learning outcome [4], also seems to be that students should learn to be critical of such monitoring tools.

NHB: At the societal level, observation is promoted as "an important part of professional expertise". At the institutional level, observation is absent in the individual subject NHB (Nature, Health and Movement) in terms of knowledge, skills and compulsory work requirements are concerned. However, those who take immersion in NHB will have "knowledge of the meaning of systematic observation". One work requirement affects observation in the NHB profile, where students should use the checklist to register what there are of organic objects and objects from nature in the kindergarten, as well as "observe how organic artefacts and natural objects are used." The use of observation methods is not stated, and what is meant by observation is rather unclear.

KKK: At the societal level, observation linked to didactic work is also associated with this area of expertise, which is reflected at the institutional level. In addition, the KKK domain (Art, Culture and Creativity) promotes children's involvement and children as participants [8.12], this is true both in the individual subjects common to all the students and further in immersion into KKK.

LSU: At the societal level, observation is associated with changes in and the development of educational practices. This is reflected at the institutional level. All students take LSU (Leadership, Cooperation and Development work), in which they conduct defined development work in a kindergarten, which incorporates a situational analysis through the use of observation or other relevant methods.

\section{Discussion}

The results demonstrate that the knowledge and skills required for observation are manifest both at the societal and institutional level and are affecting most areas of expertise.

However, the intended learning outcomes [4] vary according to what profile the students choose. The study also reveals cracks between the levels, whereby "an important part of professional expertise being the ability to observe", whilst formulated at the community level in $\mathrm{NHB}$, is not reflected at the institutional level. Mapping formulated at the societal level becomes problematized at the institutional level. The level of community and institution corresponds unequivocally with the emphasis on observation as a basis for didactic work and the development of educational practices.

At the societal level (Table 1), students are expected to possess knowledge and skills as regards the relevant methodologies of developing and learning processes. Weight is given to learning from your own practice, and developing the kindergarten as an educational instance which is emphasized by the framework plan for kindergartens [24]. At the institutional level (Table 2), the observational basis for change and development and didactic work is also evident. We also find observation of children's motor skills through the use of ongoing protocols, as well as observation of language and mathematics development, which at the community level are associated with mapping. From this, we can deduce a psychological justification for observation [12,16]. Play should also be the focus of observations to be made, among other things through participatory observation. Students shall observe children's learning processes, learning environment and groups and reflect on their own practice. This is to provide grounds for observation anchored in sociocultural thinking [16].

Prerequisite knowledge and skills in observation shall be achieved through the teaching and practice of various observation methodologies. The students are given the opportunity to be participator, experimenter and observer in educational activities in the kindergarten [8]. The document analysis showed 8 compulsory work requirements that can be linked to observation in the 3-year 
kindergarten teacher training at this institution. Only 3 of these work requirements are in individual subjects (Table 2 ), which all students have in their education regardless of their chosen profile, and are part of training and reinforcing students' knowledge and skills in observation related to the ongoing protocol, participatory observation and stories from practice. Stories from practice and ongoing protocols have greater scope than participatory observation and the overall work requirements in the individual subjects that all students take. When included the subject plan for practice, which states that "students are advised to write stories from practice every day", the practice of narratives appears as the method that clearly takes precedence over other methods of education as a whole.

At the institutional level we find in the subjects for all the students the wording "Students should know about key observation methods" as a skill in which the student can "apply key observation methods." Key observation methods are not defined, neither in the national guidelines (societal level) nor in the local course syllabuses (institutional level). In the reading syllabus common to all students, a number of methods are described; ongoing protocol, participating observation, rating scales, time sampling, logging and stories from practice. As their studies progress, and depending on what profile the students choose, the amount of observation in the curriculum is very variable. Sociograms and video observation seem to be reserved for a minority of the students. From the perspective of mandatory work requirements, a certain consensus on the ongoing protocol, participating observations and stories from practice can be taken for granted regarding key methods. Once we know that interaction is the main focus of observation work in kindergarten [18], methods such as sociograms, video observation and participatory observation will be relevant methods that kindergarten teachers should be versed in and practise. We have seen that participatory observation is clearly manifest, while sociometry and video observation seem to have little place accorded them in education. Other uses of digital tools in observation work are reserved for a few of the students. We could ask if this is an education with a functional organization [2] to secure knowledge and skills in relevant methods in the present.

What is emphasised in education and how this is worked with in education's shared activity settings [7] defines the parameters for students' learning about observation, and will determine what professional expertise in observation upcoming kindergarten teachers will possess. Birkeland \& Ødegaard[18] demonstrated that observations in kindergartens mainly focus on the child, rooted in a view of children from a developmental psychological perspective. Such emphasis is also found in education, at the societal and institutional level. This sociocultural anchoring, with a view to the teachers' own practice and that of the kindergarten, which we find on both levels, becomes ever more important to promote and strengthen in KTE, if more contemporary perspectives on children as participants are to be taken into account $[9,13,16]$. The understanding of children cannot be separated from the environment and the people who interact with them [11] or the shared activity settings [7] the children are participants in. In the reading literature, there is substantial support for this perspective, and such support should be self-evident. This also means turning one's gaze upon oneself, which Thoresen [21] regards as an ethical imperative, but as Kallestad \& Ødegaard [19] and Birkeland \& Ødegaard [18] show, it is rarely to be found in observation work in Norwegian kindergartens.

In the study on the societal and institutional levels' provisions for observation in the training of kindergarten teachers, ethics have not been made explicit enough in the learning outcome descriptions regarding observation. Thoresen [21] has underscored the need for emphasis on ethics in the training, given the asymmetrical relationship between children and adults. Paradoxically, SRLE (Society, Religion, Spirituality, and Ethics) is the only knowledge area that does not address observation in its learning outcome descriptions for upcoming kindergarten teachers.

\section{Conclusions}

White Paper no. 16 (2016-2017) The Culture of Quality in Education [6], stipulates that higher education must have clear learning outcome descriptions, so that one knows what students are actually qualified to do upon completing their education. The study's main findings, however, show that learning outcomes in observation, as are realized in HVL's course syllabuses, work requirements and syllabus, depend on which specialization/profile the students choose. The intended learning outcome [4] as regards observation is rendered very differently in the various profiles, which means that where one graduated kindergarten teacher has knowledge and skills in sociometry, another does not. Where one may have experience of video observation, another does not. One may have knowledge of the mapping tools and be able to reflect critically over the use of mapping in the kindergarten, whereas others do not.

The study demonstrates the need for discussion and clarification of key observational methods, which a kindergarten teacher should have knowledge and skills in. Such a discussion should be seen in the light of recent perspectives on children, where children are understood as part of a context, as well as different methods of theoretical grounding that can apply. In addition, the goal of a profession-oriented education [3] should be included in the discussion, set against the framework plan for kindergarten content and tasks [24]. This may be a pathway to educating professional kindergarten teachers who have expertise in observation, and who can consider and use observation methods in accordance with their intended purpose, namely in their function as upcoming kindergarten teachers.

In the study on societal and institutional level guidelines 
for observation in the training of kindergarten teaches, ethics appears to be accorded little attention in the learning outcome descriptions of observation. Thoresen [21] has underscored the need for an emphasis on ethics in the training, given the asymmetrical relationship between children and adults. I find it surprising that the only sphere of knowledge that does not address observation in the projected learning outcome descriptions is SRLE (Society, Religion, Spirituality, and Ethics). Further research should examine how the ethical perspective of observational work is safeguarded in KTE.

\section{REFERENCES}

[1] Notes on National Regulations for the Framework Plan for Kindergarten Teacher Education, The Ministry of Education and Research, Norway, 2012. Online available from:

https://www.regjeringen.no/globalassets/upload/kd/rundskri v/2012/merknader_forskrift_rammeplan_barnehagelaererut danning.pdf

[2] Teacher Education 2025: National Strategy for Quality Cooperation in Teacher Education, The Ministry of Education and Research, Norway, 2017. Online available from:

https://www.regjeringen.no/contentassets/d0c1da83bce94e 2da21d5f631bbae817/kd_teacher-education-2025_uu.pdf

[3] National guidelines for Kindergarten Teacher Education, The Ministry of Education and Research, Norway, 2012. Online available from: https://www.regjeringen.no/globalas sets/upload/kd/rundskriv/2012/nasjonale_retningslinjer_bar nehagelaererutdanning.pdf

[4] J. Haakstad. Læringsutbytte: Begrepets anvendelighet i kvalitetsvurdering av høyere utdanning (Learning Outcomes: The concept's applicability in the quality control of higher education), Uniped, Vol.34, No.4, 72-81, 2011.

[5] G. A. Bowen. Document Analysis as a Qualitative Research Method, Qualitative Research Journal, Vol.9, No.2, 27-40, 2011.

[6] White Paper no. 16 (2016-2017). The Culture for Quality in Higher Education, The Ministry of Education and Research, Norway, 2017.

[7] M. Hedegaard. Analyzing Children's Learning and Development in Everyday Settings from a Cultural-Historical Wholeness Approach, Mind, Culture, and Activity, Vol. 19, No. 2, 127-138, 2012.

[8] Framework Plan Regulations for Kindergarten Teacher Education, The Ministry of Education and Research, Norway, 2012. Online Available:

https://www.regjeringen.no/globalassets/upload/kd/rundskri v/2012/forskrift_rammeplan_barnehagelaererutdanning.pdf

[9] M. Fleer, \& M. Hedegaard. Children's Development as Participation in Everyday Practices across Different Institutions, Mind, Culture, and Activity, 17, 149-168, 2010 .
[10] A. C. Vallberg Roth. Stödja och styra. Om bedömning av yngre barn, (Support and Management. About assessment of younger children), Skolverket, Sweden, 2010.

[11] B. Bae. Observasjon i barnehagesammenheng. En problematisering (Observation in the kindergarten context. A critique). In: B. Bae, Det interessante i det alminnelige (The interesting in the ordinary), Pedagogisk Forum, Norway, 1996.

[12] I. Elfstöm. Uppföljning och utvärdering för Förändring. Pedagogisk documentation som grund för kontinuerlig verksamhetsutveckling och systematuskt kvalitetsarbete i förskolan (Monitoring and assessment for change. Pedagogical documentation as the basis for ongoing and systematic quality control in kindergartens), Doctoral thesis, Stockholms Universitet, Sweden, 2013.

[13] S. Garvis, E. E. Ødegaard \& N. Lemon. Beyond Observation-Narratives and Young Children, Sense Publishers, The Netherlands, 2015.

[14] M. Hedegaard. Beskrivelser af Småbørn (Descriptions of Young Children), Aarhus University, Denmark, 2013.

[15] I. Pramling Samuelsson. Ska barns kunskaper testas eller deras kunnande utvecklas i förskolan? (Shall Children's abilities be tested or their knowledge developed in Kindergarten?), Journal of Nordic Early Childhood Education Research, Vol.3, No.3, 159-167, 2010.

[16] V. N. Podmore \& P. Luff, Observation. Origins and Approaches in Early Childhood, Mc Graw Hill Open University Press, England, 2012.

[17] E. E. Ødegaard \& T. Krüger. Studier av barnehagen som danningsarena - sosialepistemologiske perspektiver (Studies of kindergartens as educational arenas. Socioepistemological perspectives), In: E. E. Ødegaard, Barnehagen som danningsarena (The Kindergarten as an formative arena), Fagbokforlaget, Norway, 2012.

[18] J. Birkeland \& E. E. Ødegaard. Under lupen Praksislæreres observasjonspraksis i barnehagen (Under the magnifying glass - Practice teachers' observation practice in kindergarten), Journal of Nordic Early Childhood Education Research, Vol.17, No.3, 1-18, 2018.

[19] J. H. Kallestad \& E, E. Ødegaard. Children`s activities in Norwegian kindergartens. Part 1: an overall picture, Cultural-Historical Psychology, Vol.9, No.4, 74-82, 2013.

[20] I. T. Thoresen. La småbarn komme til oss. Førskolelærerutdanningen i fokus (Let small children come to us. Kindergarten teacher training in focus), Norsk pedagogisk tidsskrift, 2005:2, 100-115.

[21] M. Bjerkestrand, J. Fiske, L. Hernes, I. Pramling Samuelsson, S. Sand, B. Simonsen, B. Stenersen, M.H. Storjord, \& R. Ullmann, Barnehagelærerutdanninga. Meir samanheng, betre heilskap, klarare profesjonsretting? Følgegruppen for barnehagelærerutdanningen (KTE. More consistency, better overview, clearer professional direction? Group for follow-through in kindergarten teacher training), Rapport nr. 2, Høgskolen i Bergen, Norway, 2015.

[22] G. Løkken, F. Søbstad. Observasjon og intervju i barnehagen. (Observation and interview in kindergarten), Universitetsforlaget, Norway, 2013. 
[23] M. Bjerkestrand, J. Fiske, L. Hernes, I. Pramling Samuelsson, S. Sand, B. Simonsen, B. Stenersen, M.H. Storjord, \& R. Ullmann, Barnehagelærerutdanninga. Tilbakevendande utfordringar og uprøvde mulegheiter, Følgegruppen for barnehagelærerutdanningen, (KTE. Recurring challenges and untried possibilities, group for follow-through in kindergarten teacher training), Rapport nr. 3, Høgskolen i Bergen, Norway, 2015.

[24] Framework plan for kindergartens, (2017). Online Available:

https://www.udir.no/globalassets/filer/barnehage/rammepla n/framework-plan-for-kindergartens2-2017.pdf

[25] L. Birkeland. Pedagogiske erobringer (Pedagogical conquests), Pedagogisk Forum, Norway. 1998. 